\begin{tabular}{c} 
Volume and Issues Obtainable at Center for Sustainability Research and Consultancy \\
Journal of Business and Social Review in Emerging Economies \\
ISSN: 2519-089X (E): 2519-0326 \\
Volume 6: Issue 2 June 2020 \\
JSRᄃ \\
Journal homepage: www.publishing.globalcsrc.org/jbsee \\
\hline
\end{tabular}

\title{
Objectification of Women through Public Discourse: Analysis of Pakistani Female Celebrities' Viral Pictures on Facebook
}

\author{
${ }^{1}$ Ayesha Qamar, ${ }^{2}$ Aasima Safdar, ${ }^{3}$ Samia Manzoor
}

${ }^{1}$ Lecturer, Department of Communication \& Media studies, Fatima Jinnah Women University, Rawalpindi Pakistan

${ }^{2}$ Assistant Professor, Department of Communication studies, Bahauddin Zakariya University, Multan Pakistan

${ }^{3}$ Assistant Professor, Department of Communication studies, Bahauddin Zakariya University, Multan Pakistan, samia.manzoor@bzu.edu.pk

\section{ARTICLE DETAILS}

\section{History}

Revised format: May 2020

Available Online: June 2020

Keywords
Objectification, females,
celebrity, Mahira $\quad$ Khan,
Mariyam Nawaz,
Yousafzai,
content analysis, Facebook

JEL Classification

MI, MO

\begin{abstract}
The present paper focused on the objectification of Pakistani female celebrities on social media especially Facebook. The comments under the viral pictures of Mahira Khan, Mariyam Nawaz and Malala Yousafzai were analyzed by adopting the objectification framework of Nussbaum and Langton. Fifty comments about each female celebrity appearing under their viral pictures were analyzed by using the technique of quantitative content analysis. Total sample consisted of 150 comments from Facebook users of both the genders, i.e. males and females. It was observed that there was an abundance of remarks under the pictures of these celebrities where objectification was at work in some way or the other. Reduction to appearance remained the most frequently occurring variable of objectification. It was also observed that though these comments were coming from people of both the genders but male users of Facebook appeared more hostile in this regard. It is suggested on the basis of the results obtained through the current research that FIA needs to formulate a more strict policy regarding online trolling and shaming.
\end{abstract}

\section{OPEN ACCESS}

(C) 2020 The authors, under a Creative Commons Attribution-

NonCommercial 4.0

Corresponding author's email address: samia.manzoor@bzu.edu.pkr

Recommended citation: Qamar, A., Safdar, A. and Manzoor, S. (2020). Objectification of Women through Public Discourse: Analysis of Pakistani Female Celebrities' Viral Pictures on Facebook. Journal of Business and Social Review in Emerging Economies, 6 (2), 651-659

\section{Introduction}

Pakistani women are diverse and varied. They belong to various backgrounds and social contexts, thus the freedom they have is subject to their circumstances, families and geographical boundaries. However the topic of women, their dressing, their personal lives and its relationship to honor is a difficult, contentious and often discussed topic. Hence it is not a surprise that celebrity women are subject to such public scrutiny and their dressing becomes a topic of widespread discussion on social media. The present research paper focused and discussed public discussions about three, famous, Pakistani, female celebrities and the memes about them on social media particularly Facebook in the 
context of theory of Objectification. This theory is defined by Nussbaum (1995) and further elaborated by Langton (2009). Martha Nussbaum (1995) identified seven features of objectification that allow us to understand how objectification manifests itself within the socio cultural contexts. Langton (2009) further elaborated the features identified by Nussbaum (1995) and added three more to it.

As Sartwell (2000) acknowledged "All of us participate in the making of narratives". It is the age of social media and we can observe that people have the ability to participate in public forums because social media provide its users liberty to participate and be a part of the public narrative. In this research we focused on the construction of social narrative by the Pakistani public on social media about female celebrities. These narratives are the reflections of beliefs, fears and aspiration of the common people of Pakistan. Therefore, the present research focused on the identification of public's rhetoric about celebrity women's body.

During the course of the present research three Pakistani celebrities, whose dressing and public behavior have remained a topic of concern and debate for the Pakistani public would be discussed. These are Mahira Khan, one of the most popular and sought after actresses of Pakistani entertainment industry. Mahira Khan 's controversial Pictures with Ranbir Kapoor went viral on 21 September 2017 and remained a topic of discussion on social media (Samaa ,2017).

Maryam Nawaz is the daughter of famous Pakistani politician and Former Prime Minister Mian Muhammad Nawaz Sharif. Maryam Nawaz has been a subject of controversy in the Panama Leaks (Geo News Live, July, 2018).

Mala Yousazai has been questioned for her fight for female education. Malala Yousafzai was shot in the head by the Taliban for being an activist for female education in Swat KPK (Husain BBC News 7 October 2013). She faced much public criticism after receiving Nobel Peace Prize in 2014 (The Telegraph 2 April 2020).

\section{Literature Review}

According to Bedford and Johnson (2006) women of every age group agonize with body shaming and undesirable feelings about their body. Objectification is a central idea within feminist theory, which aims to explore and understand how objectification is rampant within society and how it reduces women to objects rather than people. Objectification thus is the idea that women are objects and are treated as such. Dworkin (1976) defined objectivity very accurately when she said;

"It is true, and very much to the point that women are objects, Commodities, some deemed more expensive than others but it is only by asserting ones humanness every time, in all situations that one becomes someone as opposed to something."

Objectification is not some vague idea rather it has been amply explored and has developed a long tradition of understanding. Objectification theory aims to understand how women are objectified within cultural context; moreover it also aims to understand how this objectification effects the objectified.

In the words of Fredrickson and Roberts (1997) the physical appearance is usually considered the most dominant factor to differentiate between the genders. But they say that very less work has been done on the non-biological factors of the people of any gender. These factors are social and cultural standing of a gender in a system.

According to McKinley and Hyde (1996) many researches have been conducted to identify that how the life of a woman gets affected through the way her body appears. They said that beauty and appeal are not only important in the private life of a woman. but are also vital for their social stature (as cited in Hogan, Karen, 2012).

Green (2004) argued that it is permissible and also required to treat people as objects. He explained that people, however, are clearly more than objects. What is problematic therefore, according to Green, is to treat a person merely as an object, merely as a means to one's own ends. We can treat other people as means only if we at the same time respect their integrity as agents with their own purposes (Green 2000, 44). Objectification reflects how a 
society treats its women and how women are valued within their society. Objectification exhibit self-objectification, negative mood, body shame, body dissatisfaction, low self-esteem, disordered eating, anxiety, and depression (Noll \& Fredrickson, 1998).

Miguel (2016) viewed that Hollywood's endemic sexism has been manifested in a variety of ways: from the disturbing gender wage gap (which became a hot-button issue after the Sony hack revealed both Jennifer Lawrence and Amy Adams earned significantly less than their male costars in American Hustle to the hyper-sexualization of female characters and the dearth of nuanced, relatable, honest roles for women.

Davies (2016) said that black women in the limelight are not only scrutinized by onlookers and consumers but they are often devalued, hyper-sexualized, and fetishized in ways that render them mere objects that is absolutely misogynous at its highest level. It can be said that the dehumanization of celebrity women is something of a trend in media, music, and every day conversation. The nature of celebrity is admittedly odd and impersonal, as the mass public is fed an image of a person stripped of their human qualities and paraded around as the pinnacle of success and beauty. Many have argued that popular media - which increasingly featured celebrity narratives over the 1990s and 2000s perpetuates unrealistic standards of beauty and weight and sexualizes mothers' bodies (Dworkin, 2000).

\section{Conceptual Framework}

Martha Nussbaum (1999) proposed seven aspects of objectification. All of these aspects are features of our treatment of things and can be involved when we treat a "someone" as a "something." Instrumental-it implies that the objectified is treated as a tool for meeting the needs of the objectify; ownership and fungibility occur when the objectified is seen as something that can be owned, traded, or exchanged; violability refers to the lack of integrity making it permissible to hurt or destroy the objectified; the denial of autonomy and subjectivity strip the objectified of free will and personal experience; finally, inertness takes away the agency of the objectified. None of these aspects reflect a sufficient, or a necessary condition in defining objectification, but most of the time multiple aspects are present when the term is applied. While this is true for purely definitional purposes, when analyzing the moral implications of objectification Nussbaum (1999) emphasizes that instrumentality seems to be the most morally demanding aspect. "The instrumental treatment of human being is always morally problematic; if it does not take place in a larger context of regard for humanity, it is a central form of the morally objectionable" (Nussbaum, 1999, p. 238).

Kaufmann (2011) proposes a similar reasoning in his analysis of instrumentalization. He identified that a group could be humiliated in three ways. First is "direct group humiliation" (p: 22), second is "symbolic group humiliation" (p: 23) and third is "representative group humiliation" (p: 25).

Langton (1996) described the local solipsism and said that the feminists are more concerned about it because women are more often treated as things. The reduction of people to things violates the autonomy of the other person, it objectifies the person or because it makes another of other. She explained three objectified variables as reduction to body, reduction to appearance and silencing.

On the basis of the literature review and the theoretical framework the following research questions were developed, RQ1. How Pakistani female celebrities are objectified on social media?

RQ2. What are the most common variables of objectification present in the comments of people on social media?

RQ3. Is there any relationship between gender and objectification?

\section{Methodology}

This study examines the use of variables of objectification within the comments of the public on social media. The data was collected from the Facebook. The top five comments under each viral image of three famous Pakistani celebrities Mahira Khan, Malala Yousafzai and Maryam Nawaz were selected from Facebook. The coding sheet was constituted on the basis of objectification theory variables. Total 150 comments were analyzed through quantitative content analysis technique. The results are analyzed through SPSS. Correlation and Chi-square test was used for data analyses. 


\section{Operationalization of Variables \\ 5.1 Instrument}

The dealing of a person as tool for objectifies purposes. The comments are being analyzed on the bases of the words being refereed as instrument. The Mean was calculated as $(M=0.07)$ while the Standard Deviation was $(S D=0.250)$.

\subsection{Denial of Autonomy}

The handling of a person as deficient in independence and lacking in self-character and mind. The comments are being analyzed on the bases of the words being refereed as denial of autonomy. The Mean was calculated as $(M=0.06)$ while the Standard Deviation was $(S D=0.238)$.

\subsection{Inertness}

The behavior of person, lacking in action and agency also in activity was referred as inertness. The comments are being analyzed on the bases of the words being refereed as inertness. The Mean was calculated as $(M=0.15)$ while the Standard Deviation was $(S D=0.355)$.

\subsection{Ownership}

The celebrity is dealt as something that is owned by someone. The comments are being analyzed on the bases of the words being refereed as ownership. The Mean was calculated as $(M=0.29)$ while the Standard Deviation was $(S D=0.454)$.

\subsection{Fungibility}

The person is handled as interchangeable with other objects. The comments are being analyzed on the bases of the words being refereed as fungibility. The Mean was calculated as $(M=0.05)$ while the Standard Deviation was $(S D=0.212)$.

\subsection{Violability}

The dealing of person as deficient in honesty and integrity was coded as violability. The comments are being analyzed on the bases of the words being refereed as Violability. The Mean was calculated as $(M=0.42)$ while the Standard Deviation was $(S D=0.495)$.

\subsection{Denial of subjectivity}

The persons feeling and experiences don't need to be taken in account. The comments are being analyzed on the bases of the words being refereed as Denial of subjectivity. The Mean was calculated as $(M=0.06)$ while the Standard Deviation was $(S D=0.238)$.

\subsection{Reduction to body}

The treatment of a person as identifies with their body parts. The comments are being analyzed on the bases of the words being refereed as reduction to body parts. The Mean was calculated as $(M=0.13)$ while the Standard Deviation was $(S D=0.334)$.

\subsection{Reduction to appearance}

The person deals as how they look overall. The comments are being analyzed on the bases of the words being refereed as reduction to appearance. The Mean was calculated as $(M=0.65)$ while the Standard Deviation was $(S D=0.491)$.

\subsection{Silencing}

The treatment of person as lacking in capacity to speak was treated as silencing. The comments are being analyzed on the bases of the words being refereed as silencing. The Mean was calculated as $(M=0.00)$ while the Standard Deviation was $(S D=0.000)$.

\section{Findings}




\section{Cumulative Descriptive Table of Objectification Comments about Female Celebrities}

\begin{tabular}{|c|c|c|}
\hline & $\mathrm{N}$ & Sum \\
\hline Instrumentality & 150 & 10 \\
\hline Denial of Autonomy & 150 & 9 \\
\hline Inertness & 150 & 22 \\
\hline Fungibility & 150 & 7 \\
\hline Violability & 150 & 63 \\
\hline Ownership & 150 & 43 \\
\hline Denial of Subjectivity & 150 & 9 \\
\hline Reduction to Body & 150 & 19 \\
\hline Reduction to Appearance & 150 & 98 \\
\hline Silencing & 150 & \\
\hline Valid N (list wise) & 150 & \\
\hline
\end{tabular}

The above table shows the frequency of objectification variables from total number of respondents that commented on the pictures of all the three celebrities. The comments of total 150 respondents, both male and female were analyzed.

The above table indicates that objectification existed in most of the comments. However the instance of the variable Reduction to Appearance is the highest. Around 65\% people commented on the looks and appearances of the celebrities thus judging and commenting on their looks. This reduces the person to an object of beauty and attraction rather than a human being.

The second highest variable of objectivity is violability. Both male and female respondents have ruthlessly bashed the celebrities in integrity and honor. They have assumed that the person in question has no personal boundary or integrity. Hence the person that they were attacking is completely immoral and corrupt. The instance of the variable violability is $42 \%$. The third highest variable is ownership. Ownership can be described as treating someone like she is owned by someone. About $28 \%$ comments reflected the sense of ownership. The respondents claimed that the woman in question defamed the Pakistani image, Pakistani culture and religion. The variable reduction to body was also highly in the comments. Women body parts where discussed and criticized severely for their appearance. About $12 \%$ people commented under body reduction objectification. The variables denial autonomy and denial subjectivity were found in the least number of variables. Only $6 \%$ people comments under denial autonomy and denial subjectivity.

Table 2. Chi-Square Test Association between Gender and all Variables of Objectification

\begin{tabular}{|c|c|c|c|c|c|}
\hline & Value & $\mathrm{df}$ & $\begin{array}{l}\text { Asymptotic } \\
\text { Significanc } \\
\text { e (2-sided) }\end{array}$ & $\begin{array}{l}\text { Exact Sig. } \\
\text { (2-sided) }\end{array}$ & $\begin{array}{l}\text { Exact Sig. } \\
\text { (1-sided) }\end{array}$ \\
\hline Pearson Chi-Square & $3.314^{\mathrm{a}}$ & 1 & .069 & & \\
\hline $\begin{array}{l}\text { Continuity } \\
\text { Correction }^{\mathrm{b}}\end{array}$ & 2.714 & 1 & .099 & & \\
\hline Likelihood Ratio & 3.367 & 1 & .067 & & \\
\hline Fisher's Exact Test & & & & .084 & .049 \\
\hline $\begin{array}{l}\text { Linear-by-Linear } \\
\text { Association }\end{array}$ & 3.292 & 1 & .070 & & \\
\hline $\mathrm{N}$ of Valid Cases & 150 & & & & \\
\hline
\end{tabular}


a. 0 cells $(0.0 \%)$ have expected count less than 5 . The minimum expected count is 22.26 .

b. Computed only for a $2 \times 2$ table

Table 3. Gender association with Violability (Objectification variable)

Table 4. Crosstab-

\begin{tabular}{|l|l|l|l|}
\hline \multicolumn{2}{|c|}{} & \multicolumn{2}{|l|}{ Violability } \\
\cline { 3 - 4 } \multicolumn{2}{|c|}{ Sex } & no & yes \\
\cline { 2 - 4 } & $\begin{array}{l}\text { Female } \\
\text { e }\end{array}$ & 51 & 46 \\
\hline \multirow{2}{*}{ Total } & 36 & 17 \\
\hline
\end{tabular}

Chi-square test is applied to check the association between gender and all variables of objectification. It includes instrument, denial of autonomy, denial of subjectivity, inertness, fungibility, violability, body reduction, body appearance, ownership and silencing. The researchers tried to find out the association between gender and all variables and no association was found except the gender and violability. The data has been collected from 91 male and 53 female. That shows that $61 \%$ male and $33 \%$ female commented on pictures and objectified the images as violable. The chi- square value is .069 . It indicated that the association exited between the gender and violability at $10 \%$ level of significant. It verifies that the researcher is confident at $90 \%$ level.

Table 5. Correlation between the Gender and Violability

\begin{tabular}{|l|l|l|l|}
\hline \multicolumn{2}{|l|}{} & sex & Violability \\
\hline \multirow{5}{*}{ Sex } & $\begin{array}{l}\text { Pearson } \\
\text { Correlation }\end{array}$ & 1 & -.149 \\
\cline { 2 - 4 } & Sig. (2-tailed) & & .069 \\
\cline { 2 - 4 } & $\mathrm{N}$ & 150 & 150 \\
\hline \multirow{3}{*}{$\begin{array}{l}\text { person as lacking in } \\
\text { integrity }\end{array}$} & $\begin{array}{l}\text { Pearson } \\
\text { Correlation }\end{array}$ & -.149 & 1 \\
\cline { 2 - 4 } & Sig. (2-tailed) & .069 & \\
\cline { 2 - 4 } & $\mathrm{N}$ & 150 & 150 \\
\hline
\end{tabular}

The table 5 shows the correlation between the gender and violability. Pearson correlation is -.149. It indicated that female comments moves to 0 value and male comments moves towards 1 value. Females were less inclined in their comments to violability than males. And male's comments were more inclined towards violability.

Table 6. Correlation between Denial Autonomy and Inertness

\begin{tabular}{|c|c|c|c|}
\hline & & $\operatorname{sex}$ & Violability \\
\hline \multirow[t]{3}{*}{ Sex } & $\begin{array}{l}\text { Pearson } \\
\text { Correlation }\end{array}$ & 1 & -.149 \\
\hline & Sig. (2-tailed) & & .069 \\
\hline & $\mathrm{N}$ & 150 & 150 \\
\hline \multirow[t]{3}{*}{$\begin{array}{l}\text { person as lacking in } \\
\text { integrity }\end{array}$} & $\begin{array}{l}\text { Pearson } \\
\text { Correlation }\end{array}$ & -.149 & 1 \\
\hline & Sig. (2-tailed) & .069 & \\
\hline & $\mathrm{N}$ & 150 & 150 \\
\hline
\end{tabular}

The above table showed the relationship between the two variables of objectification. The denial autonomy and Inertness is correlated. The Pearson Correlation is significant at .000 levels. It indicated that both variables were significant at $5 \%$ level. The researcher is $95 \%$ confident at Pearson value of .371 . The positive values indicated that both male and female respondents commented and objectified. 


\section{Discussion}

It is the beauty of present age of social media that people have the ability to participate and be a part of the public narrative. This narrative is reflective of the beliefs, convictions and aspirations of the common man. Social media facilitate everyone to publicly share their opinion. Many instances of shaming were observed in the past including some very famous personalities (Wonderwall, 2019).

The results of the present research confirmed that humiliation by social media users mostly contains sexual objectification based on derogatory comments. The sample of 150 comments showed an explicit derogation towards famous women. Humiliating portrayals of women accelerated men's aggressiveness towards them. These portrayals further encourage people to consider women as weak, submissive and violable object (García, 2018). Likewise, women in the online environment are free to choose the life of their own. They remain on the foreground and people have ease of access and judge them. These judgments contain the freedom of expression and this freedom is sometimes detrimental. Results of the current study were also validated by another study conducted by Demirhan \& Çakır- Demirhan (2015). In their research patriarchal discourse on Twitter under the hash tag "woman has to be" were examined. The results unveiled that most of the comments under this hash tag were made by men, supporting male dominance and forcibly implementing socio-cultural women on women. Another investigation examined how society imposed certain restrictions and challenges for women on social media in India. Researchers found that besides strict surveillance by male family members, comments made by the male social media friends also contain derogation and ownership concerning the female users. Talking particularly about the selected sample of the study, pictures of Mahira Khan and Ranbir Kapoor faced much online shaming. For these reasons, Mahira was publicly humiliated by the audience and confronted "Slut-shaming". It is because people did not consider the achievements, what they only bother about is women and their stereotypical "dignity" (Images Staff, 2019a). Likewise, a picture of Mala Yousafzai became viral when she was walking on a subway in jeans, this lead to a flood of online criticism. People criticized what she was wearing and even many compared her with an adult star Mia Khalifa. Although, Malala's extraordinary story was recognized and she won the Nobel Prize as well, but for the people, her physical appearance was important over her achievements (Telegraph.co.uk, 2017) ${ }^{1}$. Our analysis showed that comments portrayed women celebrities as lacking activity, personal opinion and self-esteem. An example can be taken from the Political meeting between Maryam Nawaz and Bilawal Bhutto Zardari in June 2019. Some people called them a newly married couple and some trolled them by making suggestive comments (Images Staff, 2019b). Oakes (2019) also affirmed this phenomenon as he stated that women are still distorted the way media represent them. They lack agency and personal integrity in media portrayals. Although, new media are different than traditional media, but both equally support patriarchy and negative images of women. No matter from which professional field they belong either it is business, politics, activism, education, sports or some other. They fail to get attention, respect and honor that they deserve. Social media provide opportunities to stay more visible. This visibility makes them more vulnerable and thus vulnerability leads women to face ridicule, harassment and hate (Smith, 2019). Use of sexist language against women simply intends to demean them. Although discriminatory and objectifying language can harm people of both the genders but women become more severely harmed. Calling women with words like "slut, prostitute, whore" all are highly prevalent. On the contrary, men media discussions of men are absolutely different where they are usually referred as "players, perfect and smart" enough to have a sexualized lifestyle (Ifechelobi \& Ifechelobi, 2017).

\section{Conclusion}

Online shaming involves public shaming causing certain detrimental impacts. It involves publication of someone's private content or humiliating the other person by using sexist, derogatory and foul language. In this content analysis, we found higher levels of derogation against female celebrities in Pakistan. This derogation did not only involve comments from males but females also used language that was humiliating and sexist. The comments of Facebook that appeared under the pictures of Mahira Khan, Mariyam Nawaz and Malala Yousafzai in the context of ten properties proposed by objectification theory showed that, not only media audience tends to objectify women through public platforms but sexist remarks are made about them no matter from which field they belong. In Pakistan, where socio-cultural values are strictly tied with strings of patriarchy, women from any background have to confront

\footnotetext{
${ }^{1}$ Malala Yousafzai attacked on social media over 'photo of her wearing jeans and heels'.
} 
patriarchal sets of restrictions and humiliation. The women in Pakistan are not considered as owners of their content in the online environment. They are humiliated, harassed and publicly shamed by the other social media users. Although Federal Intelligence Agency (FIA) is counteracting against online bullying and helping many women to resolve online harassment cases, but the celebrity harassment and shaming is still a question. Pakistan's female celebrities face more shaming and derogation than their male counterparts. The patriarchal mindset does not want to allow women to deviate from their stereotypical roles. Especially, those who post their pictures online are bound to face shaming, harassment, bullying and humiliation. As affirmed by Ali (2019) every physical detail of online pictures is noticed and criticized by Pakistani audience especially men are comparatively more interested to do so. FIA needs to develop some more stict policies to deal with the culprits of online shaming and harassment.

\section{References}

Ali, S. (2019). The Gendered Media: From Structural and Representational Perspectives: Sana Ali: 9781706080220 : Amazon.com: Books. Retrieved November 12, 2019, from Amazon.com website: https://kdp.amazon.com/amazon-dp-action/us/dualbookshelf.marketplacelink/1706080220

Bedford, J.L., \& Johnson, S.C. (2006). Societal Influence on Body Image Dissatisfaction in Younger and Older Women. Journal of Women and Ageing, 18(1), pp. 41-55.

Davies, J (2017, July 7). Black twitter, culture, film, music, politics. http://blackyouthproject.com/zendayas-responseto-a-twitter-troll-highlights-the-objectification-of-women-celebs/

Demirhan, K., \& Çakır-Demirhan, D. (2015). Gender and politics: Patriarchal discourse on social media. Public Relations Review, 41(2), 308-310. https://doi.org/10.1016/j.pubrev.2014.11.010

Dworkin, A. (1976). Woman hating. New York: Dutton.

Dworkin, A. (2000). Against the male flood: Censorship, pornography, and equality. In D. Cornell (Ed.), readings in feminism: Feminism and pornography. Oxford, UK: Oxford University Press.

Fredrickson, B. L., \& Roberts, T.-A. (1997). Objectification theory: Toward understanding women's lived experiences and mental health risks. Psychology of Women Quarterly, 21, 173-206.

García, V. (2018, September 19). How media sexism demeans women and fuels abuse by men like Weinstein. Retrieved from The Conversation website: https://theconversation.com/how-media-sexism-demeans-womenand-fuels-abuse-by-men-like-weinstein-85789

Green, Leslie (2000). Pornographies, Journal of Political Philosophy, 8(1): 27-52

Husain, M. (2013, October 7). Malala: The girl who was shot for going to school. BBC News, Retrieved from https://www.bbc.com/news/magazine-24379018

Ifechelobi, C and Ifechelobi, J. N. (2017). Gender Discrimination: An Analysis of the Language of Derogation. IOSR Journal of Humanities And Social Science 22(12), 23-27.

Images Staff. (2019a, March 27). People waste no opportunity to tear down women in Pakistan, says Shehzad Roy and we agree. Retrieved November 20, 2019, from Images website: https://images.dawn.com/news/1182180

Images Staff. (2019b, May 20). Okay, so Maryam Nawaz is being trolled for sitting while female. Retrieved November 20, 2019, from Images website: https://images.dawn.com/news/1182804

Kaufmann, P. (2011). Instrumentalization: Humiliation, degradation, dehumanization: Human dignity violated.pp. 57-65. New York, NY: Springer.

Langton, R. (2009). Sexual solipsism: Philosophical essays on pornography and objectification. Oxford University Press.

McKinley, N. M.\& Hyde, J.S. (1996). The objectified Body Conscious Scale: Development and Validation. Psychology of Women Quarterly. 20, pp.181-215.

Miguel. C.S. (2016, July 30)20 Actresses Who've Spoken About the Objectification of Women in Hollywood, New Times, https://thestir.cafemom.com/celebrities/199625/20_actresses_whove_spoken_out n. d. (2018, July). Nawaz Sharif sentenced to 11, Maryam 8 years in Avenfield reference. Geo News Live, Retrieved from https://www.geo.tv/latest/201862-nawaz-sharif-sentenced-11-maryam-8-years-in-avenfield-reference n. d. (2020, April 2). Malala Yousafzai wins Nobel Peace Prize 2014. The Telegraph, Retrieved from https://www.telegraph.co.uk/news/worldnews/asia/pakistan/11153447/Malala-Yousafzai-wins-Nobel-Peace-

Prize-2014.html

Noll, S. M., \& Fredrickson, B. L. (1998). A Mediational Model Linking Self-Objectification, Body Shame, and Disordered Eating. Psychology of Women Quarterly, 22(4), 623-636. https://doi.org/10.1111/j.1471- 
6402.1998.tb00181.x

Nussbaum, M. (1995). Objectification. Philosophy and Public Affairs, 24(4): 24291.Retreived from, https://plato.stanford.edu/entries/feminism-objectification/

Nussbaum, M. (1999) Sex and Social Justice, Oxford: Oxford University Press. Retrieved from https://plato.stanford.edu/entries/feminism-objectification/

Nussbaum, M. C. (1995). Objectification. Philosophy \& Public Affairs, 24(4), 249-291.

Oakes, K. (2019). The complicated truth about social media and body image. Retrieved from bbc.com website: https://www.bbc.com/future/article/20190311-how-social-media-affects-body-image

Samaa digital (2017, november17). Does Mahira Khan have any Bollywood projects lined up? Retreived from https://www.samaa.tv/culture/2017/11/does-mahira-khan-have-any-bollywood-projects-lined-up/

Sartwell, C. (2000). End of story. Albany: State University of New York Press.

Smith, G. (2019). Women's voices ‘invisible’ thanks to social media gender bias. Retrieved November 19, 2019, from Newswise.com website: https://www.newswise.com/articles/women-s-voices-invisible-thanks-to-socialmedia-gender-bias

Telegraph.co.uk. (2017, October 18). Malala Yousafzai attacked social media over 'photo of her wearing jeans and heels.' Retrieved November 20, 2019, from The Telegraph website: https://www.telegraph.co.uk/news/2017/10/18/malala-yousafzai-attacked-social-media-photo-wearing-jeansheels/

Wonderwall. (2019, April 23). Celebs who've been parent-shamed on social media. Retrieved November 19, 2019, from Wonderwall.com website: https://www.wonderwall.com/celebrity/social-media/celebs-been-parentshamed-social-media-mom-shamed-dad-shamed-3009328.gallery 